\title{
Flow Variation of the Major Tributaries of Tigris River Due to Climate Change
}

\author{
Nahlah Abbas' ${ }^{1}$, Nadhir Al-Ansari ${ }^{2}$, Saleh Wasimi ${ }^{1}$, Abdulla M. Al-Rawabdeh ${ }^{3}$ \\ ${ }^{1}$ School of Engineering \& Technology, Central Queensland University, Melbourne, Australia \\ ${ }^{2}$ Department of Civil, Environmental and Natural Resources Engineering, Luleå University of Technology, Luleå, Sweden \\ ${ }^{3}$ Department of Earth and Environmental Science, Yarmouk University, Irbid, Jordan \\ Email: n.abbas@cqu.edu.au, „nadhir.alansari@ltu.se, s.wasimi@cqu.edu.au, abd_rawabdeh@yu.edu.jo
}

How to cite this paper: Abbas, N., Al-Ansari, N., Wasimi, S. and Al-Rawabdeh, A.M. (2019) Flow Variation of the Major Tributaries of Tigris River Due to Climate Change. Engineering, 11, 437-442.

https://doi.org/10.4236/eng.2019.118031

Received: July 17, 2019

Accepted: August 18, 2019

Published: August 21, 2019

Copyright (c) 2019 by author(s) and Scientific Research Publishing Inc. This work is licensed under the Creative Commons Attribution International License (CC BY 4.0).

http://creativecommons.org/licenses/by/4.0/

cc) (i) Open Access

\begin{abstract}
Iraq relies greatly on the flow of the Euphrates and Tigris Rivers and their tributaries. Five tributaries namely Khabour, Greater Zab, Lesser Zab, AlAdhiam and Daylia, which are the major tributaries of Tigris River, sustain Northern Iraq Region, a semi-arid, mainly a pastureland. These tributaries contribute about $24 \mathrm{~km}^{3}$ of water annually. The discharge in the tributaries, in recent times, has been suffering increasing variability contributing to more severe droughts and floods apparently due to climate change. This is because there were no dams constructed outside Iraq previously. For an appropriate appreciation, Soil Water Assessment Tool (SWAT) model was used to evaluate the impact of climate change on their discharge for a half-centennial lead time to 2046-2064 and a centennial lead time to 2080-2100. The suitability of the model was first evaluated, and then, outputs from six GCMs were incorporated to evaluate the impacts of climate change on water resources under three emission scenarios: A1B, A2 and B1. The results showed that water resources are expected to decrease with time.
\end{abstract}

\section{Keywords}

Tigris River, Streamflow, SWAT, Climate Change

\section{Introduction}

Currently, there is growing evidence that climate change would boost extreme weather events such as tropical cyclones, floods, droughts and bushfires affecting water resources of a region [1]. The effects on the hydrological cycle are mainly through the change of evapotranspiration and precipitation [2] [3]. These modifications, in extreme cases, manifest as severe droughts and floods, which could 
induce radical transformation in river, discharge regime and soil moisture [4]. The Middle East region is considered as an arid to semi-arid region where the annual precipitation does not exceed $166 \mathrm{~mm}$ annually. Iraq was considered as an exception due to the presence of the Tigris and Euphrates Rivers. After the seventies, the flow of the two main rivers started to decrease. This is due to the effect of climate change on the region where what was used to be known as the Fertile Crescent started to die 30 years ago. This fact encourages the riparian countries to build dams to safeguard their needs for water. As a consequence, the flow of the two rivers entering Iraq decreased. In addition, IPCC [5] has identified Iraq as highly vulnerable to climate change. The adverse effects of climate change on water resources could negatively influence the environment and the economy of the country, particularly the agricultural sector. Iraqi decision makers are now seeking predictions about the potential impacts of climate change including changes in the duration and magnitude of precipitation, which has ramifications on sustaining and managing water resources to alleviate water scarcity problem that has become pronounced [6]. The main five tributaries of Tigris River are the backbone of water resources of northern region Iraq. So far, water issues related to climate change in these catchments have not been well addressed within climate change analyses and climate policy construction [7]. This study aims to fill that gap, and to achieve that objective, the mathematical modeling tool SWAT is used since it has demonstrated satisfactory performance when applied to other similar regions in the past [8].

\section{Study Area}

Tigris River has five major tributaries namely Khbour, Greater Zab, Lesser Zab, Al-Adhaim and Diyala Rivers (Figure 1). These tributaries are located in the left bank of the Tigris River between latitudes $33.2^{\circ} \mathrm{N}$ and $37.3^{\circ} \mathrm{N}$ and longitudes $42.9^{\circ} \mathrm{E}$ and $46.9^{\circ} \mathrm{E}$ and have significant contributions to Tigris flow. These tributaries are shared between Iraq and Turkey or Iraq and Iran except Al-Adhaim River. The characteristics of the basin of each tributary are summarized in Table 1. These tributaries supply about 24 cubic kilometers of water annually to the River Tigris which is $50 \%$ of the Tigris basin water.

\section{Description of the SWAT Model}

The Soil and Water Assessment Tool (SWAT) model [8], used in this study, is a river watershed scale, semi distributed and physically based discrete time (daily computational time step) model for analyzing hydrology and water quality at various watershed scales with varying soils, land use and management conditions on a long-term basis. The United States Department of Agriculture (USDA) and the Agricultural Research Service (ARS) originally developed the model. SWAT system is embedded within a Geographic Information System (ArcGIS interface) in which different spatial environmental data, including climate, soil, land cover and topographic characteristics can be integrated. 


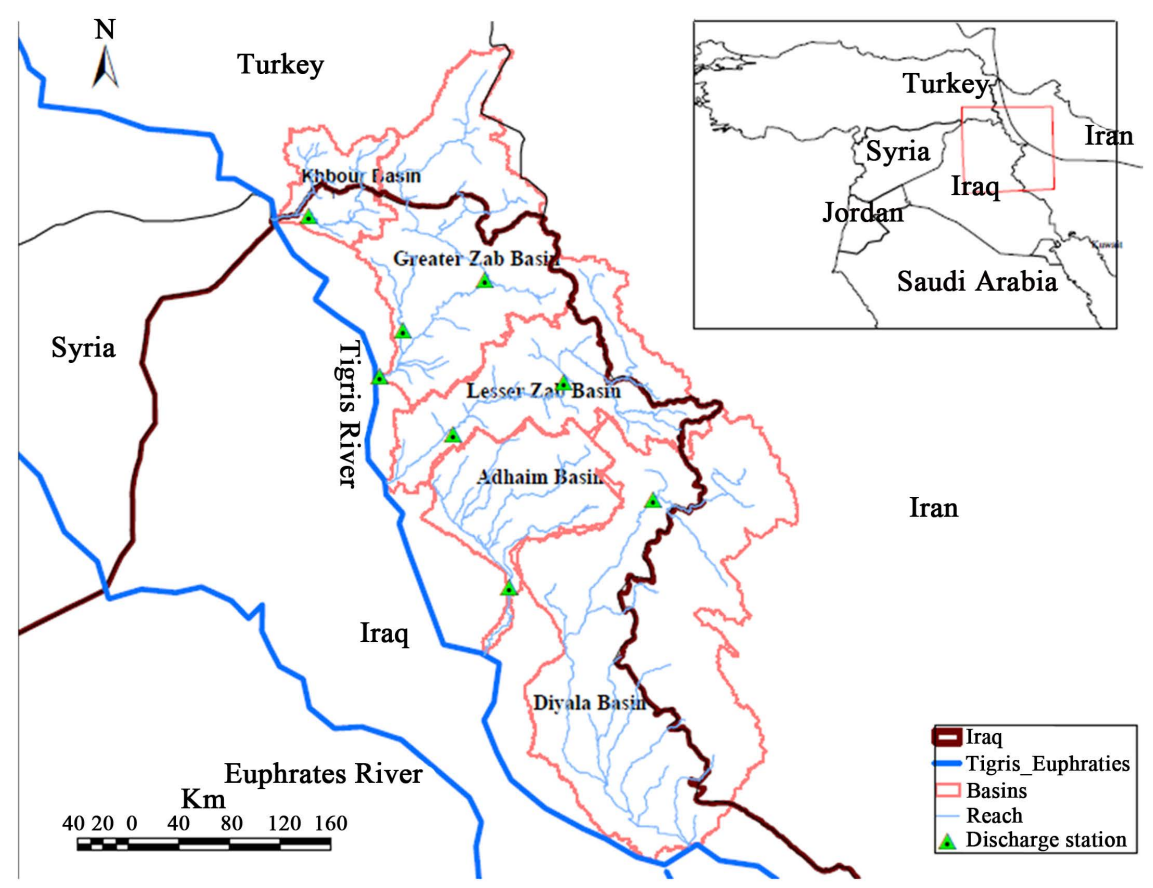

Figure 1. Map of study area.

Table 1. Characteristics of the tributaries of River Tigris.

\begin{tabular}{cccccc}
\hline River & Khbour & Greater Zab & Lesser Zab & Al-Adhaim & Diyala \\
\hline $\begin{array}{c}\text { Basin area } \\
\left(\mathrm{Km}^{2}\right)\end{array}$ & 6143 & 26,473 & 15,600 & 13,000 & 33,240 \\
$\begin{array}{c}\text { Basin area shares } \\
(\%)\end{array}$ & $\begin{array}{c}\text { Iraq } 43 \% \\
\text { Turkey } 57 \%\end{array}$ & $\begin{array}{c}\text { Iraq } 65 \% \\
\text { Turkey } 35 \%\end{array}$ & $\begin{array}{c}\text { Iraq } 80 \% \\
\text { Iran 20\% }\end{array}$ & Iraq 100\% & $\begin{array}{c}\text { Iraq 75\% } \\
\text { Iran 25\% }\end{array}$ \\
$\begin{array}{c}\text { River length } \\
(\text { Km })\end{array}$ & $181 \mathrm{~km}$ & $462 \mathrm{~km}$ & $302 \mathrm{~km}$ & 230 & $574 \mathrm{~km}$ \\
$\begin{array}{c}\text { Maximum annual } \\
\text { flow (BCM) }\end{array}$ & 4.3 & 23.6 & 15.1 & 1.2 & 14.4 \\
$\begin{array}{c}\text { Minimum } \\
\text { annual flow (BCM) }\end{array}$ & 0.9 & 3.7 & 1.7 & 0.4 & 1.2 \\
$\begin{array}{c}\text { Mean annual flow } \\
(\mathrm{BCM})\end{array}$ & 2 & 12.7 & 7.8 & 0.80 & 4.6 \\
Dams & Unregulated & Unregulated \\
to date & to date & 2 & 1 & 3 \\
\hline
\end{tabular}

\subsection{Model Input}

Enormous amount of input data is required by SWAT model to fulfill the tasks envisaged in this research. Basic data requirements for modeling included digital elevation model (DEM), land use map, soil map, weather data and discharge data. DEM was extracted from ASTER Global Digital Elevation Model (ASTERGDM) with a 30 meter grid and $1 \times 1$ degree tiles. The land cover map was obtained from the European Environment Agency (https://www.eea.europa.eu/) with a 250 meter grid raster for the year 2000. The soil map was collected from the 
global soil map of the Food and Agriculture Organization of the United Nations [9]. Weather data included daily precipitation, 0.5 hourly precipitation, maximum and minimum temperatures obtained from the Iraq's Bureau of Meteorology. Monthly streamflow data was collected from the Iraqi Ministry of Water Resources/National Water Centre.

\subsection{Model Setup}

In SWAT model, the watershed is divided into sub-basins based on the digital elevation model (DEM). The land use map, soil map and slope datasets were embedded with the SWAT databases. Thereafter, sub-basins are further delineated by Hydrologic Response Units (HRUs). HRUs are defined as packages of land that have a unique slope, soil and land use area within the borders of the sub-basin. HRUs enable the user to identify the differences in hydrologic conditions such as evapotranspiration for varied soils and land usage. Routing of water and pollutants are predicted from the HRUs to the sub-basin level and then through the river system to the watershed outlet. A HRU is the smallest mesh size in the SWAT model.

\subsection{General Circulation Model (GCM) Inputs}

Six GCMs from CMIP3 namely CGCM3.1/T47, CNRMCM3, GFDL-CM2.1, IPSLCM4, MIROC3.2 (medres) and MRI CGCM2.3.2 were selected for climate change projections in the Lesser Zab basin under a very high emission scenario (A2), a medium emission scenario (A1B) and a low emission scenario (B1) for two future periods (2046-2064) and (2080-2100). The projected temperatures and precipitation were then input to the SWAT model to compare water resources in the basin with the baseline period (1982-2010). BCSD method was used to downscale the GCM results [10].

\section{Results and Discussion}

The results from the hydrological modelling for annual stream flow are shown in Figure 2. Khbour, Al-Adhiam and Diyala stream flow will significantly decrease in the six models for all scenarios (A2, A1B, B) for both time periods. Apart of MRI, Greater Zab stream flow will experience decreases for all scenarios for both periods. Lesser Zab stream flow will decreases under A2 and A1B, however will experience increases under B1 for both periods. The decrease of flow of the Euphrates and Tigris Rivers and their tributaries in the last decade was discussed in details by [11] [12]. In view of these results, it is believed that Iraq should rely on non-conventional water resources to minimize the water shortage problem.

\section{Conclusion}

The results from the SWAT model clearly demonstrate that the water regime of the five basins will undergo a shift due to climate change, and most likely, for the worse. The recent trends in the availability of water resources as observed in the 


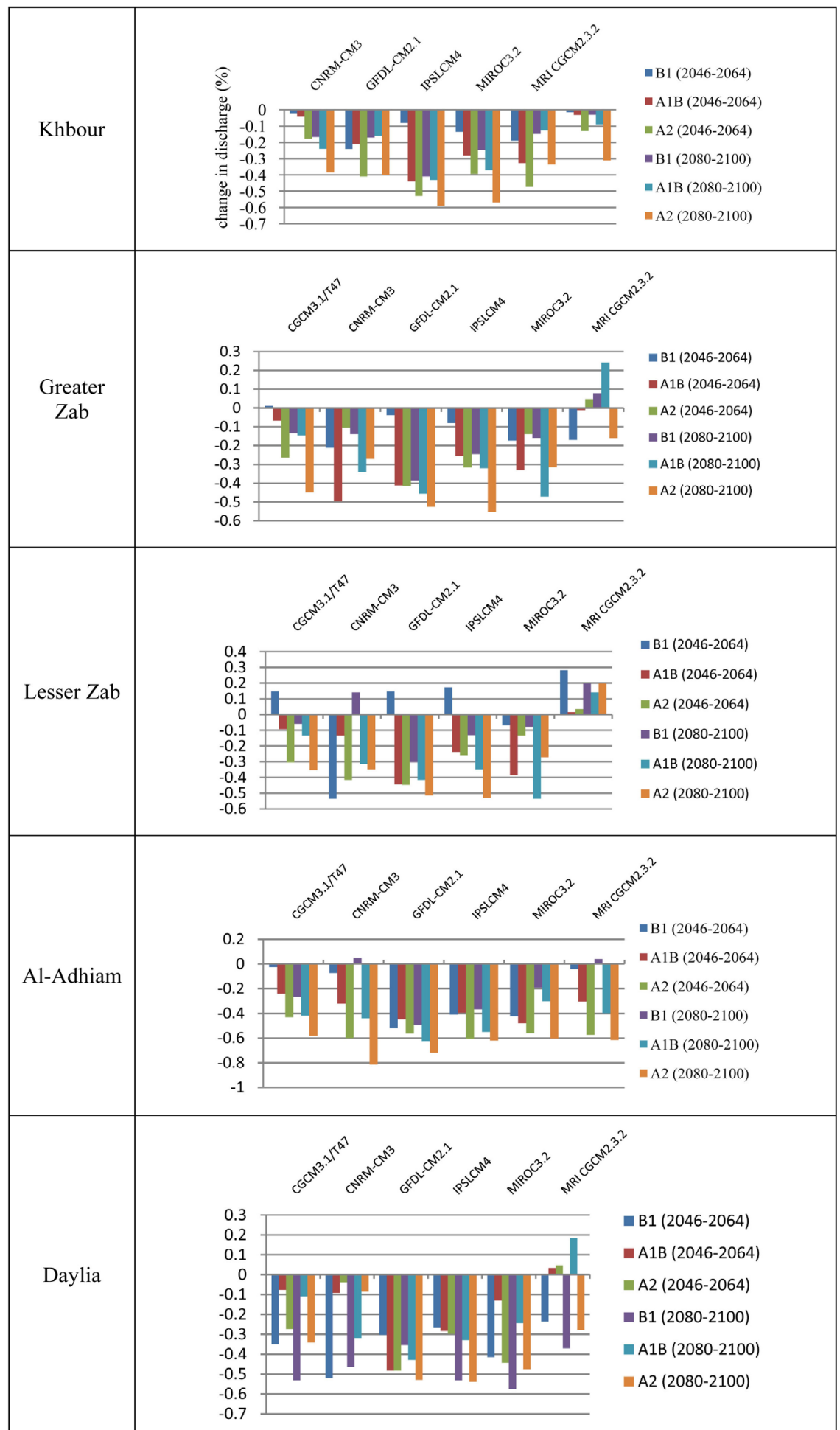

Figure 2. Projected changes in stream flow in the five basins compared to the base-period 1982-2000, for 2046-2064 and 2080-2100. For B1, A1B and A2 scenarios.

latest decades corroborate the fact that the phenomenon might have already started. Since water is a scarce resource in the region, a strategy to deal with the adversity of the future is warranted. Undoubtedly, a pro-active action or an early 
intervention should be considered to overcome the expected water scarcity. In this context, non-conventional water resources might overcome this shortage. Water harvesting techniques and wastewater treatment and reuse might solve or minimize the effect.

\section{Conflicts of Interest}

The authors declare no conflicts of interest regarding the publication of this paper.

\section{References}

[1] Keenan, T. and Cleugh, H. (2011) Climate Science Update: A Report to the 2011 Garnaut Review. Centre for Australian Weather and Climate Research, Canberra.

[2] Mimikou, M., Baltas, E., Varanou, E. and Pantazis, K. (2000) Regional Impacts of Climate Change on Water Resources Quantity and Quality Indicators. Journal of Hydrology, 234, 95-109. https://doi.org/10.1016/S0022-1694(00)00244-4

[3] Coffey, R.P., Benham, B.L. and Krometis, L.-A. (2014) Assessing the Effects of Climate Change on Waterborne Microorganisms: Implications for EU and US Water Policy. Human and Ecological Risk Assessment. An International Journal, 20, 724-742. https://doi.org/10.1080/10807039.2013.802583

[4] Owor, M., Taylor, R.G., Tindimugaya, C. and Mwesigwa, D. (2009) Rainfall Intensity and Groundwater Recharge: Empirical Evidence from the Upper Nile Basin. Environmental Research Letters, 4, Article ID: 035009. https://doi.org/10.1088/1748-9326/4/3/035009

[5] IPCC (2007) Climate Change 2007: Impacts, Adaptation and Vulnerability: Contribution of Working Group II. Fourth Assessment Report of the Intergovernmental Panel on Climate Change. Cambridge University Press, Cambridge.

[6] Al-Ansari, N., Ali, A.A. and Knutsson, S. (2014) Present Conditions and Future Challenges of Water Resources Problems in Iraq. Journal of Water Resource and Protection, 6, 1066-1098. https://doi.org/10.4236/jwarp.2014.612102

[7] Issa, I.E., Al-Ansari, N., Sherwany, G. and Knutsson, S. (2014) Expected Future of Water Resources within Tigris-Euphrates Rivers Basin, Iraq. Journal of Water Resource and Protection, 6, 421-432. https://doi.org/10.4236/jwarp.2014.65042

[8] Arnold, J.G., Srinivasan, R., Muttiah, R.S. and Williams, J.R. (1998) Large Area Hydrologic Modeling and Assessment Part I: Model Development. Journal of the American Water Resources Association, 34, 73-89. https://doi.org/10.1111/j.1752-1688.1998.tb05961.x

[9] Food and Agriculture Organization (1995) The Digital Soil Map of the World and Derived Soil Properties, Version 3.5. FAO, United Nations, Rome.

[10] Maurer, E.P., Brekke, L., Pruitt, T., Thrasher, B., Long, J., Duffy, P., Dettinger, M., Cayan, D. and Arnold, J. (2014) An Enhanced Archive Facilitating Climate Impacts and Adaptation Analysis. Bulletin of the American Meteorological Society, 95, 1011-1019. https://doi.org/10.1175/BAMS-D-13-00126.1

[11] Al-Ansari, N., Adamo, N., Sissakian, V., Knutsson, S. and Laue, J. (2018) Geopolitics of the Tigris and Euphrates Basins. Journal of Earth Sciences and Geotechnical Engineering, 8, 187-222.

[12] Al-Ansari, N. (2019) Hydro Geopolitics of the Tigris and Euphrates. In: Mustafa, Y., Sadkhan, S., Zebari, S. and Jacksi, K., Eds., Recent Researches in Earth and Environmental Sciences, Springer, Berlin, 35-70.

https://doi.org/10.1007/978-3-030-18641-8_4 